\title{
Growth of papaya seedlings on substrate consisting of poultry litter biochar
}

\section{Crescimento de mudas de mamoeiros em substrato constituído por biocarvão de cama de aviário}

\author{
Laysa Gabryella de Souza Laurentino; Lucia Helena Garófalo Chaves²*; Antônio \\ Ramos Cavalcante3; Jean Pereira Guimarães3; Felipe Guedes de Souza3; \\ Washington Benevenuto de Lima ${ }^{3}$; Josely Dantas Fernandes ${ }^{4}$; Edilma Rodrigues \\ Bento Dantas ${ }^{5}$; André Alisson Rodrigues da Silva ${ }^{3}$; Hugo Orlando Carvallo Guerra ${ }^{2}$
}

\section{Highlights}

Poultry litter biochar improves the development of papaya seedlings. Maximum DQI was 2.89, achieved at the biochar rate of $14.5 \mathrm{t} \mathrm{ha}^{-1}$.

The biochar rates of 8 and $12 \mathrm{t} \mathrm{ha}^{-1}$ provided the best results.

Papaya cultivar Ouro stood out over cultivar Formosa.

\section{Abstract}

The choice of a substrate that meets the nutritional and physical demands of papaya seedlings with the use of organic wastes is directly linked to increases in crop yield and is an important environmental and economic alternative. Aiming to produce good-quality papaya seedlings while considering the composition and availability of substrates, this study examined the influence of applying increasing rates of poultry litter biochar as a substrate component in the production of papaya seedlings. The study was developed in a protected environment belonging to the Federal University of Campina Grande (UFCG). The experiment was laid out in a completely randomized design with a $6 \times 2$ factorial arrangement consisting of six rates of biochar (4, 8, 12, 16 and $20 \mathrm{t} \mathrm{ha}^{-1}$ and the control) and two papaya cultivars (Formosa and Ouro), with four replicates. Plant height, stem diameter, number of leaves and leaf area were evaluated 90 days after sowing. The fresh and dry biomass of shoots and root system and the Dickson Quality Index were also evaluated. In

1 Student of the Master's Course of the Postgraduate Program in Agricultural Engineering, Universidade Federal de Campina Grande, UFCG, Campina Grande, PB, Brazil. E-mail: laysaagabryella@live.com

2 Full Profs., Agricultural Engineering Department, UFCG, Campina Grande, PB, Brazil. E-mail: Ingarofalo@hotmail. com; hugo_carvallo@hotmail.com

${ }^{3}$ Students of the Doctoral Course of the Postgraduate Program in Agricultural Engineering, UFCG, Campina Grande, PB, Brazil. E-mail: antoniosoledade@gmail.com; jean.p.guimaraes@gmail.com; felipeguedes.eng@gmail.com; washi_bene@yahoo.com.br; andrealisson_Cgpb@hotmail.com

${ }_{4}^{4}$ Postdoctoral Student, Agricultural Engineering Department, UFCG, Campina Grande, PB, Brazil. E-mail: joselysolo@ yahoo.com.br

${ }^{5}$ Dra Researcher, Civil Engineering Department, UFCG, Campina Grande, PB, Brazil. E-mail: edilma.dantas@hotmail. com

* Author for correspondence

Received: July 31, 2021 - Approved: Sept. 10, 2021 
conclusion, the rates that provided good development of papaya seedlings were 8 and $16 \mathrm{t} \mathrm{ha}^{-1}$, and papaya cultivar Ouro showed better growth results.

Key words: Biochar. Carica papaya L.. Growth. Pyrolysis.

\section{Resumo}

A escolha de um substrato que atenda às demandas nutricionais e físicas de mudas de mamoeiro com o uso de resíduos orgânicos, está diretamente ligada ao incremento da produção da cultura e se configura como uma importante alternativa ambiental e econômica. Com o intuito de produzir mudas de mamão de boa qualidade, levando em consideração a composição e a disponibilidade de substratos, objetivou-se avaliar a influência da aplicação de doses crescentes de biocarvão de cama de aviário como componente de substrato na produção de mudas de mamoeiro. O trabalho foi conduzido em ambiente protegido, pertencente a Universidade Federal de Campina Grande - UFCG. O delineamento estatístico utilizado foi o inteiramente casualizado em esquema fatorial $6 \times 2$, constituído de 6 doses de biocarvão $(4,8,12,16$ e $20 \mathrm{t} \mathrm{ha}^{-1} \mathrm{e}$ a testemunha) e duas variedades de mamoeiro (Formosa e Ouro) com 4 repetições. Foram avaliadas as variáveis altura da planta, diâmetro caulinar, número de folhas e área foliar aos 90 dias após o semeio. Também foram avaliadas as fitomassas fresca e seca da parte aérea e do sistema radicular e o Índice de Qualidade de Dickson. Conclui-se que as doses que proporcionaram um bom desenvolvimento das mudas de mamoeiro foram 8 e 16 t ha-1 $^{-1}$ e a variedade mamão Ouro apresentou os melhores resultados de crescimento.

Palavras-chave: Biocarvão. Carica papaya L.. Crescimento. Pirólise.

\section{Introduction}

Fruit production is one of the main sectors of the Brazilian agricultural economy, given the large job offer and income generation for the country (Paixão et al., 2020). In this respect, papaya (Carica papaya L.) is considered one of the most important fruit crops produced in tropical and subtropical regions (Lima et al., 2016). Though preferably consumed in its natural state, industrialization processes enable its use in the food, textile, pharmaceutical and animal feed industries. The main papaya-producing countries are India, Brazil and Nigeria, which represent $64 \%$ of the world's papaya production $(8,097,651 \mathrm{t})$ (Empresa Brasileira de Pesquisa Agropecuária [EMBRAPA], 2019). In 2018, Brazil had a total production of $1,060,392 \mathrm{t}$ of the fruit, distributed across 27,000 ha of cultivated area
(Instituto Brasileiro de Geografia e Estatística [IBGE], 2018).

Seedling production is one of the most important stages in papaya growing. The substrate and the volume of containers influence seedling formation, providing appropriate conditions for germination and root system growth (Mesquita et al., 2012). In this sense, the choice of a substrate that meets the nutritional and physical requirements of seedlings, as well as is accessible to the producer, is directly linked to the success of the crop (Siqueira, Chagas, Martins, Oliveira, \& Silva, 2020). Thus, low-cost alternative materials that can be used in the constitution of new substrates have been sought, e.g., agricultural and industrial wastes. With the use of these materials, costs can be reduced and seedling quality enhanced. 
Biochar represents a strategy for improving plant growth conditions, as its properties increase water and nutrient retention in the soil and improve plant productivity, in addition to bringing benefits to the environment thanks to carbon sequestration. Biochar originates from the pyrolysis of plant or animal biomass in the absence of or at low oxygen. Several raw materials can be used for the production of biochar; however, the nature of the biomass is a factor that interferes with the final condition of the product.

Waste from intensive chicken farming is rich in nutrients, and because it is available on the farms at a low cost, it can be used by producers to fertilize commercial crops. According to Empresa Paranaense de Assistência Técnica e Extensão Rural [EMATER] (2011), the main components of poultry litter are nitrogen $(\mathrm{N})$, phosphorus $(\mathrm{P})$ and potassium $(\mathrm{K})$, which are also the main components of mineral fertilizers.

However, although poultry litter has several benefits when applied directly to the soil, it also comes with issues that can hinder its use, such as environmental pollution and proliferation of disease vectors due to the agglomeration of organic products and the generation of pathogenic microorganisms. Additionally, poultry litter contains some products used in bird management, such as antibiotics and hormones that can negatively affect the ecosystem through runoff and leaching (Young et al., 2016).

To minimize these impacts, one of the effective and sustainable destinations of poultry litter is its use as biomass for the production of biochar, as it acts in a quickly, economically and timely manner for the disposal of the litter. Additionally, biochar functions as a carbon store, improves soil quality and can be used as a corrective for acidity and as a source of nutrients, especially phosphorus and potassium (Tito et al., 2020).

This study proposes to examine the growth of seedlings of two papaya cultivars (Carica papaya L.) on substrate with the application of increasing rates of biochar from the pyrolysis of poultry litter.

\section{Material and Methods}

The experiment was conducted in a greenhouse at the Department of Agricultural Engineering at the Federal University of Campina Grande, Paraíba, Brazil (07013'11" S, 355' $31^{\prime \prime}$ W). Soil samples were collected from the $0-20 \mathrm{~cm}$ deep layer in the Agreste region of Paraíba, whose analysis revealed the following attributes, according to Teixeira, Donagema, Fortana and Texeira (2017): $\mathrm{pH}$ $\left(\mathrm{H}_{2} \mathrm{O}\right)=5.75 ; \mathrm{ECse}=0.16 \mathrm{dS} \mathrm{m}^{-1} ; \mathrm{Ca}=1.56$ cmolc kg-1; $\mathrm{Mg}=1.18 \mathrm{cmolc} \mathrm{kg}^{-1} ; \mathrm{Na}=0.06$ cmolc kg-1; $\mathrm{K}=0.26 \mathrm{cmolc} \mathrm{kg}^{-1} ; \mathrm{H}=1.27 \mathrm{cmolc}$ $\mathrm{kg}^{-1} ;$ organic matter $=14.8 \mathrm{~g} \mathrm{~kg}^{-1} ; \mathrm{P}=4.9 \mathrm{mg}$ $\mathrm{kg}^{-1}$; clay $=158.5$; silt $=120.7$; and sand $=720.8$ $\mathrm{g} \mathrm{kg}^{-1}$.

Biochar was produced from a pyrolysis process whereby the poultry litter was subjected to thermal decomposition at a temperature of $450{ }^{\circ} \mathrm{C}$, in the absence of oxygen. After production, the biochar samples were analyzed chemically according to the Manual of Official Analytical Methods for Fertilizers and Correctives (Ministério da Agricultura, Pecuária e Abastecimento [MAPA], 2014), which revealed the following composition: $\mathrm{pH}\left(\mathrm{H}_{2} \mathrm{O}\right)=9.45 ; \mathrm{N}=3.45 \% ; \mathrm{P}=$ 7.78\%; $\mathrm{K}=4.90 \% ; \mathrm{Ca}=6.83 \% ; \mathrm{Mg}=1.34 \% ; \mathrm{S}$ 
$=0.76 \% ; \mathrm{Fe}=0.46 \% ; \mathrm{Cu}=0.04 \% ; \mathrm{Zn}=0.08 \%$; $\mathrm{Mn}=0.09 \% ; \mathrm{B}=0.01 \% ;$ organic carbon $=$ $39.77 \%$; organic matter $=68.56 \% ; \mathrm{C} / \mathrm{N}=$ $11.53 \%$; and CEC = $388.90 \mathrm{mmolc} / \mathrm{kg}$.

The experiment was laid out in a completely randomized design with a $6 \times 2$ factorial arrangement corresponding to six biochar rates $\left(0,4,8,12,16\right.$ and $\left.20 \mathrm{t} \mathrm{ha}^{-1}\right)$ and two papaya cultivars (V1 = Formosa and V2 = Ouro), with four replicates, totaling 48 experimental units.

To set up the experimental units, which consisted of plastic polyethylene bags $(15 \times$ $28 \mathrm{~cm}$ ) with holes for water drainage, the entire material (soil, vermiculite and biochar) had its particle size homogenized by sieving through a 2-mm mesh to separate the remaining coarse material. The units were established from a mixture of soil and vermiculite at a 10:1 ratio $(1100 \mathrm{~g}$ of soil to $110 \mathrm{~g}$ of vermiculite), which were added through increasing levels of biochar and left in incubation for a period of 90 days. Soil moisture was kept close to field capacity. Vermiculite was added to the soil to make it less dense and compact, as well as airier.

After the incubation period, samples of substrate (soil mixture, vermiculite and biochar) were collected from the experimental units, airdried, ground, sieved through a 2-mm mesh and analyzed according to the methodology proposed by Teixeira et al. (2017).

Sowing was carried out in each experimental unit using four seeds, which were distributed equidistantly and at a depth of 2 $\mathrm{cm}$ from the substrate. After 14 days, when the seedlings were $5 \mathrm{~cm}$ tall, thinning was performed to keep the plant more vigorous in each experimental unit.
The water content in the substrates (soil + vermiculite + biochar) was determined weekly from gravimetric analysis of the experimental units (one replicate of each treatment). Based on the results, the volume of water needed to keep the substrates close to field capacity was calculated. The substrates were irrigated manually daily, with a watering can, to improve seed germination and seedling emergence and development. No mineral fertilization was used in the experiment.

Plant height $(\mathrm{PH}, \mathrm{cm})$ was determined with a millimeter ruler, from the neck to the insertion of the last leaf; stem diameter (SD, $\mathrm{mm}$ ) was measured with a digital caliper at the plant neck; the number of leaves (NL) was counted from the basal leaf to the last open leaf; and leaf area (LA, $\mathrm{cm}^{2}$ ) was determined according to the methodology proposed by Alves and Santos (2002). The measurements were performed 90 days after sowing, as proposed by Tofanelli, Santos, Schafhauser and Kogeratski (2018) and R. V. D. Silva, Rodrigues, Silva, Silva and Martins (2019).

Subsequently, the seedlings were harvested to determine the fresh and dry biomass of shoots (leaves and stem) and root system. To determine the fresh biomass, the plants were sectioned into leaves, stems and roots and weighed on an analytical balance, so shoot fresh biomass (SHFB) was obtained. After carefully removing and washing the rots, root length $(\mathrm{RL})$ was measured. The total fresh biomass was calculated as the sum of shoot and root fresh biomass (all values expressed in $\mathrm{g}$ ).

To determine the dry biomass, the collected material was placed in Kraft paper bags and placed to dry in a forced-air oven at a temperature of $60{ }^{\circ} \mathrm{C}$ for $72 \mathrm{~h}$, then weighed 
on an analytical scale with $0.01 \mathrm{~g}$ precision to determine shoot dry biomass (SHDB), root dry biomass (RDB) and total dry phytomass (TDB) (all values were also expressed in $\mathrm{g}$ ).

The biomass parameters were determined using the Dickson Quality Index (DQI), which considers the balance of biomass distribution in the plant, by weighting the results of several important parameters used to assess seedling quality, such as the morphological parameters of height, diameter and biomass (Medeiros et al., 2018). The DQI was determined using Equation 2 (Dickson, Leaf, \& Hosner, 1960):

$$
D Q I=\frac{\mathrm{TDB}}{\frac{\mathrm{SH}}{\mathrm{ND}}+\frac{\mathrm{SHDB}}{\mathrm{RDB}}} \quad \mathrm{Eq} .2
$$

where DQI = Dickson Quality Index; TDB = total dry biomass (g); $\mathrm{SH}=$ shoot height $(\mathrm{cm})$; SHDB = shoot dry biomass (g); ND = neck diameter $(\mathrm{mm}) ;$ and RDB = root dry biomass $(\mathrm{g})$.

Results were subjected to the homogeneity test (Cochran and Bartlett) and the normality test (Shapiro-Wilk). When a significant effect was detected, polynomial regression analysis was used for the biochar rates and mean comparison was performed for the cultivars by Student's T-test $(p<0.05)$ (Ferreira, 2011).

\section{Results and Discussion}

After the application of biochar to the soil and incubation for 90 days, the biochar rates significantly influenced the chemical properties of the soil (Table 1).

Though significant, the effect of biochar rates for both tested regression models (linear and quadratic), had a coefficient of determination $\left(R^{2}\right)$ lower than 0.50 for calcium. Thus, in the discussion of results, this regression will not be discussed. Nonetheless, all biochar rates contributed to increasing the calcium levels in the substrates, which favored seedling development, especially at the rates 8 and 12 t ha $^{-1}$, which corresponded to 4.37 and $6.76 \mathrm{cmolc} \mathrm{kg}^{-1}$ calcium in substrates.

\section{Table 1}

F test for $\mathrm{pH}$, electrical conductivity (EC), calcium (Ca), magnesium (Mg), sodium (Na), potassium (K), organic carbon $(C)$ and phosphorus $(P)$ in the soil after the period of incubation with biochar

\begin{tabular}{|c|c|c|c|c|c|c|c|c|c|}
\hline \multirow{2}{*}{$\begin{array}{l}\text { Source of } \\
\text { variation }\end{array}$} & \multirow{2}{*}{ DF } & \multicolumn{8}{|c|}{ Mean square } \\
\hline & & $\mathrm{pH}$ & EC & $\mathrm{Ca}^{1}$ & $\mathrm{Mg}$ & $\mathrm{Na}$ & $\mathrm{K}$ & $\mathrm{C}$ & $P$ \\
\hline Rates & 5 & ** & ** & $* *$ & $* *$ & ** & $* *$ & ** & * \\
\hline Linear & 1 & ** & ** & * & ** & ** & ** & ** & ** \\
\hline Quadratic & 1 & $* *$ & ns & $* *$ & $* *$ & ns & $* *$ & ns & $* *$ \\
\hline Deviation & 3 & * & $* *$ & $* *$ & ns & ns & $* *$ & ns & ns \\
\hline Residual & 18 & 0.009 & 0.008 & 0.006 & 1.37 & 0.01 & 0.02 & 2.33 & 6696.06 \\
\hline \multirow[t]{2}{*}{ CV (\%) } & & 1.41 & 8.84 & 12.56 & 13.74 & 9.19 & 5.49 & 9.04 & 37.43 \\
\hline & & & $\mathrm{dS} \mathrm{m}^{-1}$ & \multicolumn{4}{|c|}{ 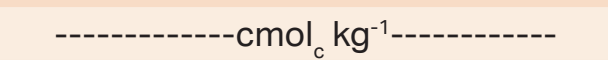 } & $\mathrm{g} \mathrm{kg}^{-1}$ & $\mathrm{mg} \mathrm{kg}^{-1}$ \\
\hline Mean & & 7.06 & 1.02 & 0.60 & 8.53 & 1.12 & 2.51 & 16.90 & 218.61 \\
\hline
\end{tabular}

DF: degree of freedom; * $e^{\star *}$ : significant at $(0.05 \leq p)$ and $(0.01 \leq p)$ error probability. ns: not significant; CV: coefficient of variation; $1=1 / \sqrt{ } \times$ transformed data. 
The soil $\mathrm{pH}$ values increased quadratically after the addition of biochar, with the highest value (7.55) occurring at the rate of $17.18 \mathrm{t} \mathrm{ha}^{-1}$ (Figure 1A), corresponding to a $25 \%$ increase relative to the control $(\mathrm{pH}$ 6.05 at the rate of 0 ). This increase in soil $\mathrm{pH}$ was already expected, given that the $\mathrm{pH}$ of the poultry litter biochar was 9.45. Changes in soil $\mathrm{pH}$ occur when biochar cations remove aluminum (Al) from clay and/or organic matter exchange sites, causing it to react with soluble monomeric Al species, or due to the subsequent dissolution of hydroxides and carbonates (Lucchini, Quilliam, Deluca, Vamerali, \& Jones, 2014). Therefore, biochar acts in the soil as an acidity corrector.

According to Oliveira, Souza, Raij and Magalhães (2004), the appropriate $\mathrm{pH}$ range for the papaya crop is between 5.5 and 6.7. In the present study, after the incorporation of increasing rates of biochar (Figure $1 \mathrm{~A}$ ), the soil $\mathrm{pH}$ values were within the ideal range up to a certain rate. However, values that lie outside this range induce physiological imbalances, as they affect the availability of nutrients, consequently influencing plant development.
Electrical conductivity (EC) in the substrate increased linearly with biochar and reached the value of $1.45 \mathrm{dS} \mathrm{m}^{-1}$ at the rate of $20 \mathrm{t} \mathrm{ha}^{-1}$. This increase is related to the increase in exchangeable bases of calcium, magnesium, potassium and sodium, available in biochar.

According to Ayers and Westcot (1999), the papaya crop is considered moderately tolerant to the threshold soil salinity at EC levels between 3 and $6 \mathrm{dS} \mathrm{m}^{-1}$. The maximum level of mean root-zone salinity that can be tolerated by plants without negatively affecting their development and productive capacity is similar (Maas \& Hoffman, 1977). However, in the present study, substrates that received more than $10 \mathrm{t} \mathrm{ha}^{-1}$ of biochar and

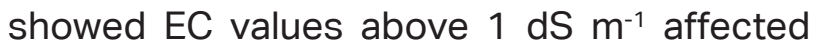
the behavior of the papaya seedlings. Diniz et al. (2018) analyzed the tolerance index of papaya seedlings to salinity in irrigation water and observed that these seedlings fitted the quadratic mathematical model, with the

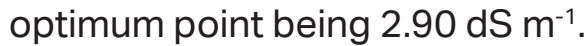


A

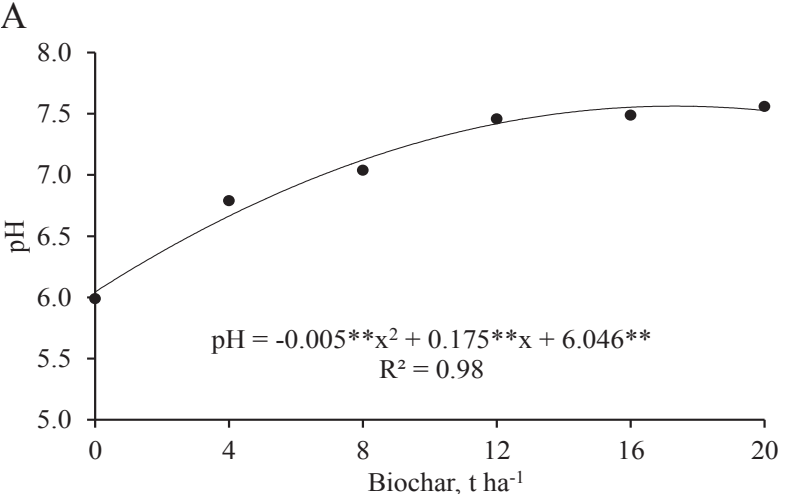

C

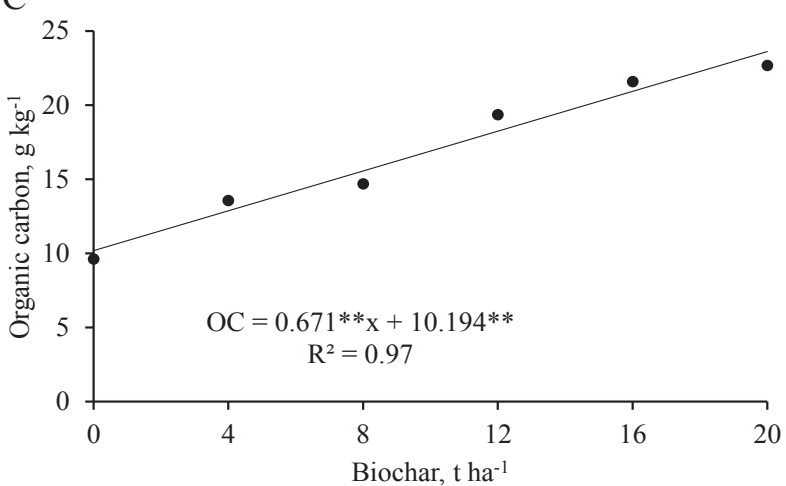

E

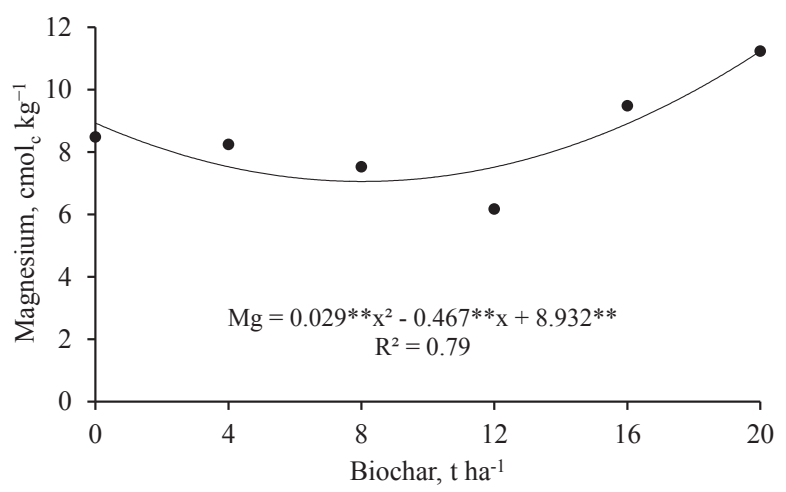

B

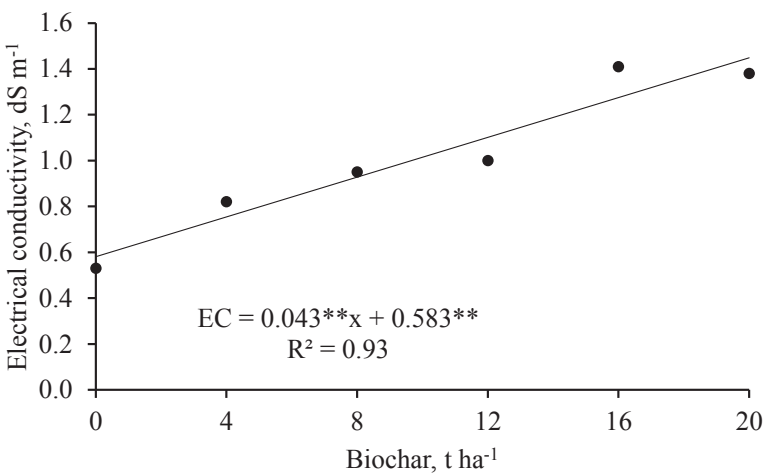

D

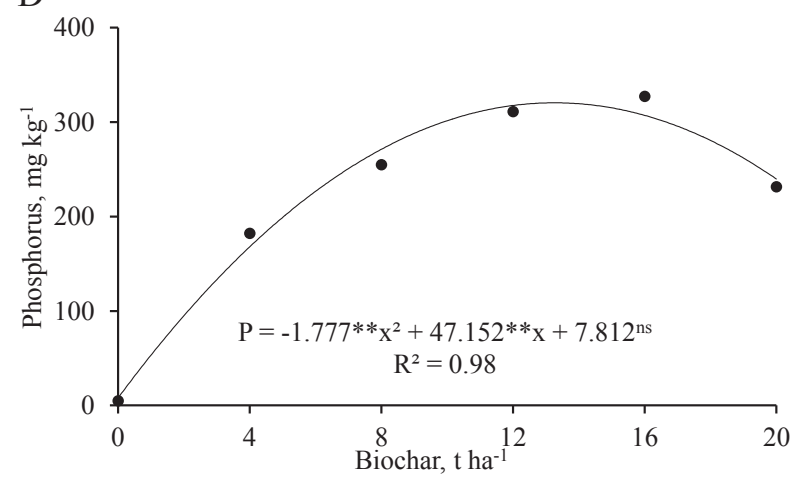

F

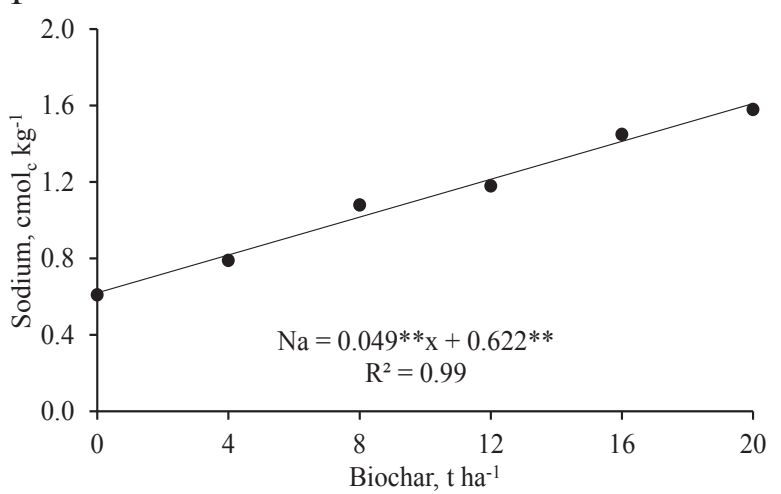

G

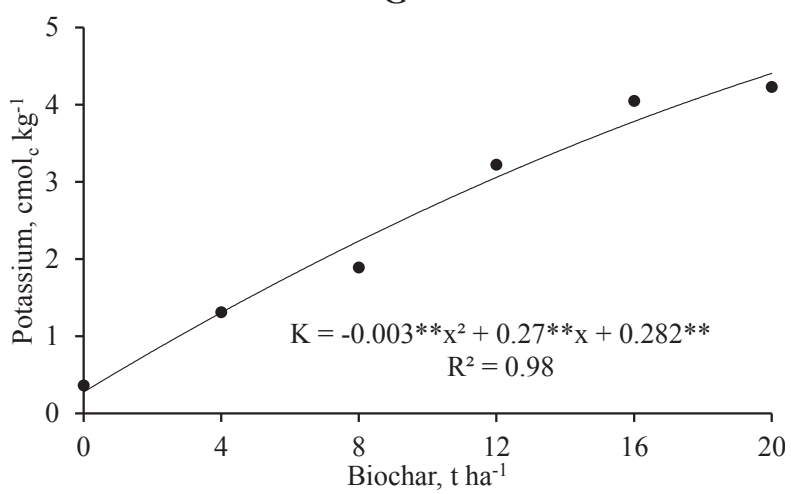

Figure 1. $\mathrm{pH}(\mathrm{A})$, electrical conductivity (B), organic carbon (C), phosphorus (D), magnesium (E), sodium (F) and potassium (G) after the substrate incubation period with the biochar treatments. 
The soil organic carbon content increased linearly with the increasing biochar rates (Figure 1C). This is likely because biochar also undergoes biodegradation, although it is considered stable in the soil system (I. C. B. D. Silva, Fernandes, Colen, \& Sampaio, 2017).

Available phosphorus increased with biochar, with the highest concentration (312.68 $\mathrm{mg} \mathrm{dm}^{-3}$ ) occurring at the rate of $13.26 \mathrm{t} \mathrm{ha}^{-1}$ (Figure 1D). This represents a $3905 \%$ increase compared with the control, corroborating Tito et al. (2020), who observed a $5131 \%$ increase in the $P$ content. This significant increase is probably due to the direct supply of this element, which acted as a source of $\mathrm{P}$, since potassium phosphate is part of the composition of biochar (Chaves et al., 2020); and to the reduced adsorption of $P$ on the surface of mineral and organic colloids that was negatively charged due to the increase in pH (Cui, Wang, Fu, \& Ci, 2011; Zhai et al., 2015).

The exchangeable cation (magnesium, sodium and potassium) content increased linearly and quadratically with the concentrations of poultry litter biochar, agreeing with previous studies (I. C. B. D. Silva, et al., 2017; Tito et al., 2020). Figures 1E, 1F and $1 \mathrm{G}$ show that the magnesium, sodium and potassium concentrations $(11.19,1.61$

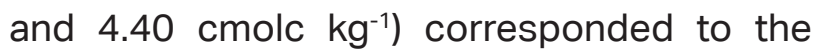
highest biochar rate $\left(20 \mathrm{t} \mathrm{ha}^{-1}\right)$; therefore, these values increased by approximately 26 , 160 and $1.492 \%$, respectively, compared with the control. The release of these elements in the soil influences plant growth, as occurred in this study regarding seedling development. In other words, because potassium is the second nutrient most required by the crop, where it exerts numerous functions, mainly as an activator of over 60 enzymes, it influences its growth. Likewise, despite being less required than potassium, magnesium is essential in photosynthesis, participating in metabolic processes such as ATP formation in the chloroplasts and acting in protein synthesis and other functions. However, when absorbed and accumulated in large amounts in the plant, the element sodium becomes highly toxic at different physiological levels and can cause negative nutritional effects such as decreased absorption of cationic nutrients, such as $\mathrm{Ca}$, $\mathrm{Mg}$ and $\mathrm{K}$, by competitive inhibition and direct toxicity, causing leaf dryness and decreased growth rate (Taiz \& Zeiger, 2013).

According to analysis of variance, the biochar rates, the cultivars and the interaction between rates and cultivars significantly influenced the biometric results of plant height, leaf diameter and leaf area. On the other hand, the number of leaves was influenced only by the biochar rates and papaya cultivars (Table 2). 


\section{Table 2}

Analysis of variance of traits of plant height, stem diameter, number of leaves and leaf area of papaya cultivars under biochar rates.

\begin{tabular}{ccccc} 
Source of variation & \multicolumn{4}{c}{ Mean square } \\
\cline { 2 - 5 } Rate (R) & Plant height & Stem diameter & Number of leaves & Leaf area \\
Cultivar (V) & $181.37^{* *}$ & $13.78^{* *}$ & $2.87^{* *}$ & $83798.50^{* *}$ \\
R $\times$ V & $142.49^{* *}$ & $2.16^{*}$ & $25.52^{* *}$ & $95824.30^{* *}$ \\
Rate within V1 & $69.57^{* *}$ & $4.91^{* *}$ & $0.97^{\text {ns }}$ & $54340.10^{* *}$ \\
Linear & & & - & $49.75 \mathrm{~ns}$ \\
Quadratic & $8.57^{\text {ns }}$ & $0.09^{\text {ns }}$ & - & $90757.36^{* *}$ \\
Deviation & $385.71^{* *}$ & $19.16^{* *}$ & - & $31519.18^{* *}$ \\
Rate within V2 & $96.28^{* *}$ & $7.81^{* *}$ & & \\
Linear & $246.47^{* *}$ & $20.04^{* *}$ & - & $461881.90^{* *}$ \\
Quadratic & $288.42^{* *}$ & $29.90^{* *}$ & - & $35789.97^{*}$ \\
Deviation & $12.23^{\text {ns }}$ & $0.28^{\text {ns }}$ & - & $2552.16^{\text {ns }}$ \\
Residual & 5.72 & 0.38 & 0.69 & 5569.73 \\
CV & 5.86 & 4.98 & 8.82 & 16.26 \\
& $\mathrm{~cm}$ & $\mathrm{~mm}$ & unit & $\mathrm{cm}^{2}$ \\
Mean & 40.85 & 12.38 & 9.40 & 459.0
\end{tabular}

${ }^{*},{ }^{* *}$ significant at 0.05 and 0.01 probability, respectively, and ns not significant, by the $\mathrm{F}$ test; $\mathrm{CV}$ : coefficient of variation.

Plant height is an important variable in papaya, as it is a parameter that determines the appropriate period for transplanting. Seedling height data showed a better fit to the quadratic model, with the highest heights of 43.88 and $47.23 \mathrm{~cm}$ seen at the rates of 10.48 and $12.68 \mathrm{t} \mathrm{ha}^{-1}$ for cultivars Formosa and Ouro, respectively (Figure 2A). Cultivar Ouro responded better than Formosa for this variable. This was likely due to the genetic difference between these plants, which had different physiological and phytotechnical traits, since the experiment was conducted equally for both cultivars. 
A

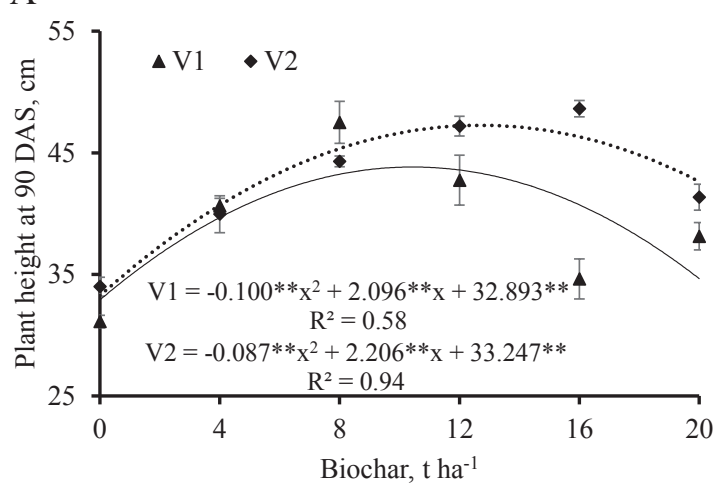

$\mathrm{C}$

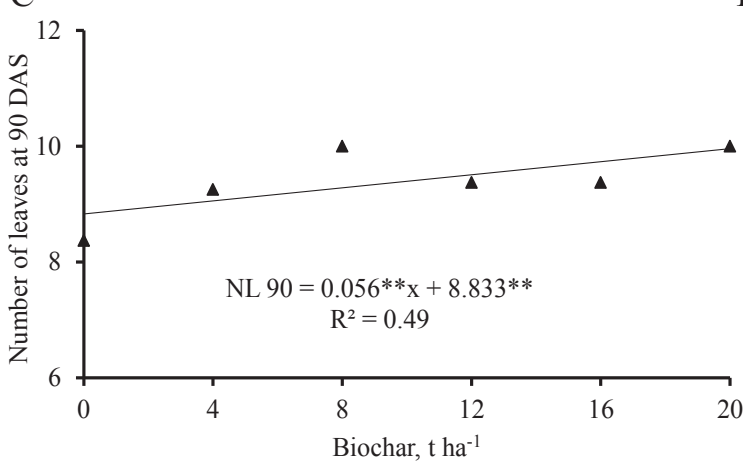

$\mathrm{E}$
B

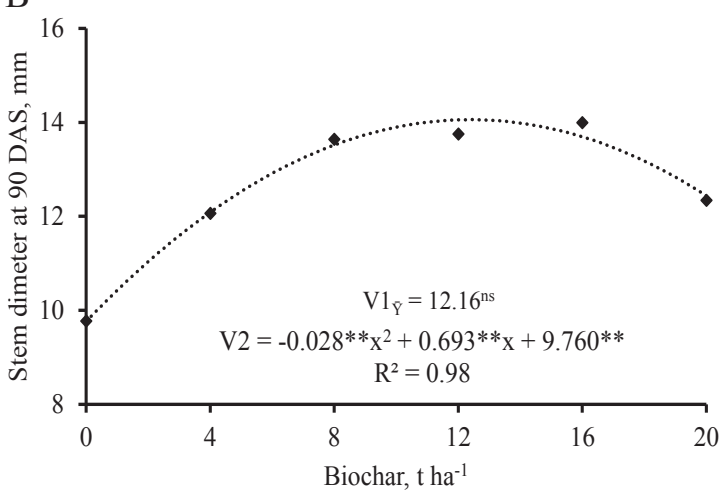

$\mathrm{D}$

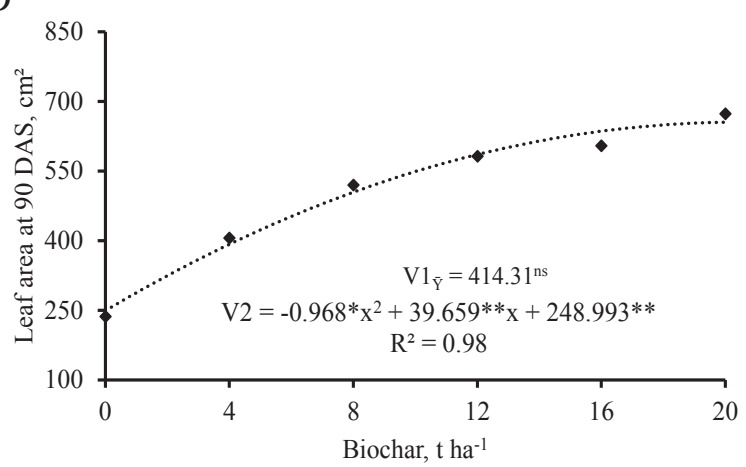

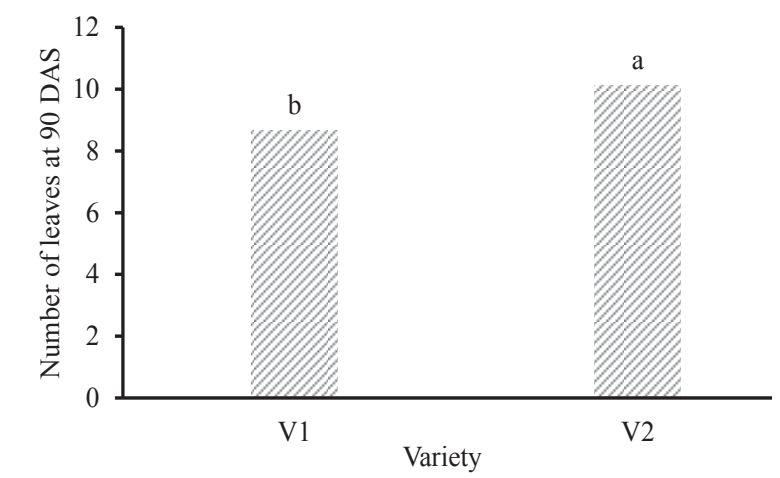

Figure 2. Plant height (A), stem diameter (B) and leaf area (D) as a function of the interaction between rates and cultivar (V1 = Formosa and V2 = Ouro) and number of leaves as a function of the isolated effect of rates of biochar (C) and cultivars (E). Means followed by the same letters do not differ between cultivars within the same rate.

Stem diameter is a parameter of fundamental importance that is related to the survival and development capacity of the seedling in the field. In the present study, the stem diameter data fit the quadratic model (Figure 2B), with an estimated maximum value of $14.05 \mathrm{~mm}$ at the rate of $12.375 \mathrm{t} \mathrm{ha}^{-1}$. This represents an increase of approximately $44 \%$ when compared with the zero rate. Stem diameter is directly influenced by water availability, so the rate of $12.375 \mathrm{t} \mathrm{ha}^{-1}$ likely provided greater water retention, which favored the increase in this variable. 
Number of leaves increased linearly, and the regression equation illustrated in Figure $2 \mathrm{C}$ shows that the plants reached an estimated value of around 10 leaves at the rate of $20 \mathrm{t} \mathrm{ha}^{-1}$. In the comparison between cultivars (Figure 2E), V2 (10.12 leaves) stood out with a difference of $16.86 \%$ compared with V1 (8.66 leaves). The increase in number of leaves of papaya seedlings is a highly important factor for photosynthesis; additionally, leaves constitute reserve centers, auxins sources and cofactors for rooting.

The influence of the above-mentioned rate on number of leaves may be related to the considerable levels of phosphorus (P) and potassium $(\mathrm{K})$ in the papaya growing substrate, since these nutrients influence the emission and size of leaves (Hoffmann, Gerling, Kyiogwom, \& Mané-Bielfeldt, 2001). In addition, phosphorus has an energy storage function, is a component of lipids and accelerates root formation (J. V. G. Silva et al., 2021).

Leaf area is considered one of the most important biological characteristics in growth analysis, as it affects photosynthesis, crop respiration rate and growth rate (Morgado, Bruckner, Rosado, Assunção, \& Santos, 2013). Higher leaf area values provide larger photosynthetic areas, thus increasing the production of photoassimilates and consequently providing more vigorous and good-quality seedlings (Santos et al., 2014). As shown in Figure 2D for the interaction between rate and cultivars, the data fit the quadratic polynomial model with the biochar levels, with a maximum of $655.2 \mathrm{~cm}^{2}$ at the rate 20.48 t ha $^{-1}$. The increasing biochar rates likely contributed indirectly to the increase in leaf area as a consequence of the higher organic matter content in the substrates. This higher content improves their structure by reducing plasticity and cohesion, increasing water- holding capacity and aeration and allowing greater penetration and distribution of roots. This chain of events is favorable for the plant to maintain a larger leaf surface in the aerial part (Hafle, Santos, Ramos, Cruz, \& Melo, 2009). Biochar stands out as a viable alternative for presenting a stable form of organic matter, as observed in the present study, where the proportion of organic matter in the soil grew by $131.65 \%$ as the rate was increased from 0 to 20 t ha-1 $^{-1}$ (Figure 1C).

According to analysis of variance, there is a significant interaction effect between the factors of biochar rates and papaya cultivars on stem fresh biomass, shoot fresh biomass, root fresh biomass and total fresh biomass, demonstrating that both factors act on jointly on these variables. Leaf fresh biomass was significantly affected by the rate and cultivar factors separately, at $1 \%$ probability. There was no statistical difference for root system length (Table 3). The absence of significant differencesindicates that the papaya seedlings exhibited the same distribution pattern for root length, regardless of the biochar rate applied in the composition of the substrate.

According to the regression equation, the leaf fresh biomass data (Figure $3 \mathrm{~A}$ ) fit the quadratic polynomial model with the biochar rates. The highest value for leaf fresh biomass was $11.08 \mathrm{~g}$, observed at the rate of $12 \mathrm{t} \mathrm{ha}^{-1}$, constituting a $109 \%$ increase when compared with the control. Between the cultivars (Figure 3B), 'Ouro' (V2) stood out with a difference of $27.88 \%$ as compared with 'Formosa' (V1), with respective values of $10.64 \mathrm{~g}$ and $8.32 \mathrm{~g}$. Stem fresh biomass data showed a quadratic behavior, with a maximum value of $26.45 \mathrm{~g}$ at the rate of $10.22 \mathrm{t} \mathrm{ha}^{-1}$ for $\mathrm{V} 1$, unlike $\mathrm{V} 2$, which had a maximum value of $30.58 \mathrm{~g}$ at the rate of 12.77 t ha $^{-1}$ (Figure 3C). 


\section{Table 3}

Analysis of variance of the traits of leaf fresh biomass (LFB), stem fresh biomass (STFB), shoot fresh biomass (SHFB), root fresh biomass (RFB), total fresh biomass (TFB) and root length (RL) of papaya cultivars under biochar rates

\begin{tabular}{|c|c|c|c|c|c|c|}
\hline \multirow{2}{*}{ Source of variation } & \multicolumn{6}{|c|}{ Mean square } \\
\hline & LFB & STFB & SHFB & RFB & TFB & $\mathrm{RL}$ \\
\hline Rate (R) & $45.99^{* *}$ & $565.22^{* *}$ & $920.52^{* *}$ & $577.5^{* *}$ & $38.88^{* *}$ & $233.61^{\mathrm{ns}}$ \\
\hline Cultivar (V) & $64.54^{* *}$ & $96.73^{*}$ & $319.3^{* *}$ & $135.34^{* *}$ & $2819.13^{\text {ns }}$ & $363.00^{\text {ns }}$ \\
\hline$R \times V$ & $12.87^{\mathrm{ns}}$ & $152.19^{* *}$ & $241.11^{* *}$ & $67.08^{* *}$ & $398.38^{* *}$ & $356.65^{\text {ns }}$ \\
\hline \multicolumn{7}{|l|}{ Rate within V1 } \\
\hline Linear & - & $31.7^{\mathrm{ns}}$ & $67.28^{\text {ns }}$ & $418.93^{* *}$ & $821.97^{* *}$ & - \\
\hline Quadratic & - & $922.4^{* *}$ & $1468.64^{* *}$ & $688.89 * *$ & $4169.23^{* *}$ & - \\
\hline Deviation & - & 326.89 & 454.01 & 162.12 & 1105.78 & - \\
\hline \multicolumn{7}{|l|}{ Rate within V1 } \\
\hline Linear & - & $802.11^{* *}$ & $1622.46^{* *}$ & $371.11^{* *}$ & $3545.48^{* *}$ & - \\
\hline Quadratic & - & $849.95^{* *}$ & $1283.30^{* *}$ & $622.8^{* *}$ & $3694.1^{* *}$ & - \\
\hline Deviation & - & 0.07 & 1.46 & 211.62 & 179.82 & - \\
\hline Residual & 7.09 & 0.38 & 0.69 & 5569.73 & 70.78 & 146.03 \\
\hline \multirow[t]{2}{*}{ CV (\%) } & 28.08 & 4.98 & 8.82 & 16.26 & 15.26 & 29.25 \\
\hline & ----- & ---------- & ------g------ & ----------- & ----- & $\mathrm{cm}$ \\
\hline Mean & 9.48 & 21.13 & 30.61 & 24.52 & 55.13 & 41.31 \\
\hline
\end{tabular}

*, ** significant at 0.05 and 0.01 probability, respectively, and ns not significant, by the $\mathrm{F}$ test; $\mathrm{CV}$ : coefficient of variation. 
A

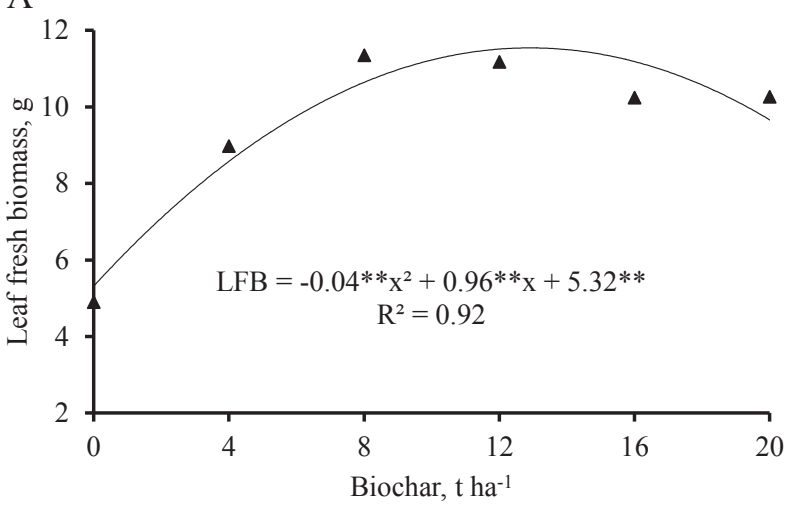

$\mathrm{C}$

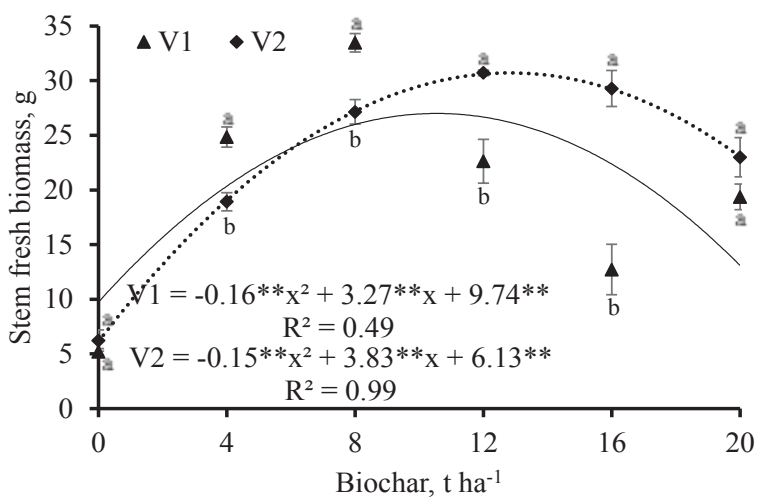

E

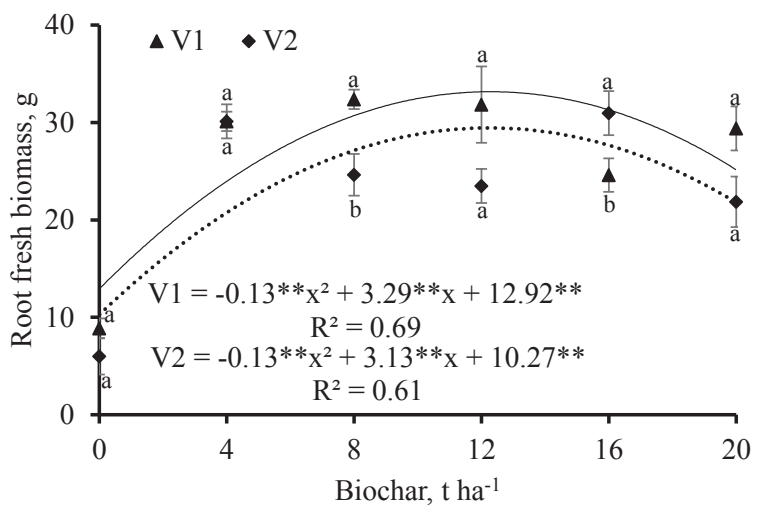

$\mathrm{B}$

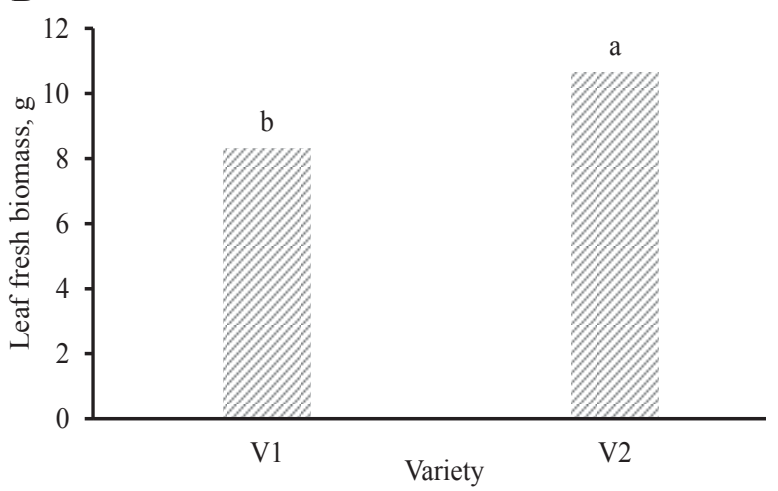

$\mathrm{D}$

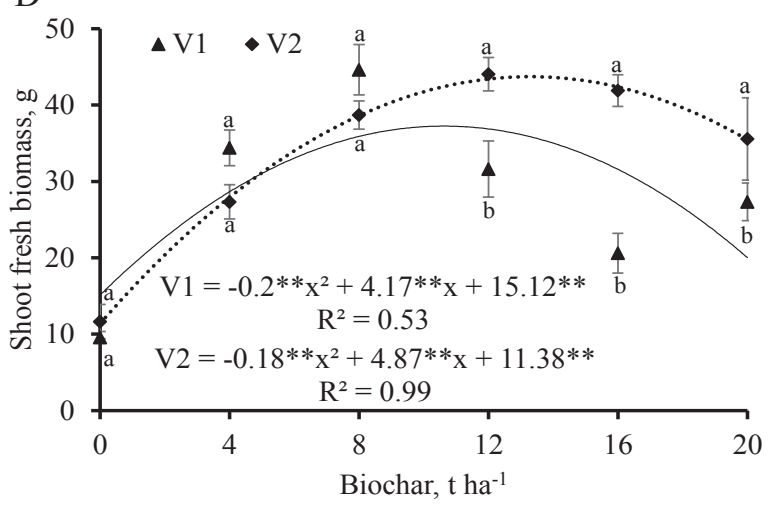

F

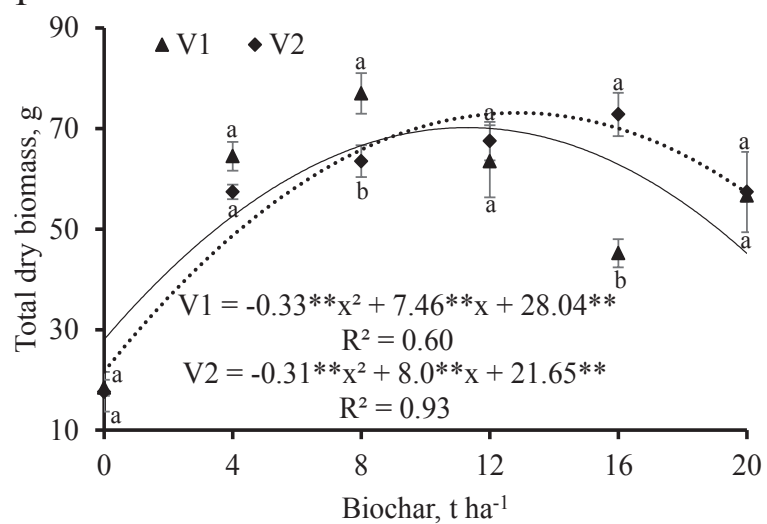

Figure 3. Leaf fresh biomass as a function of the isolated effect of biochar rate (A) and the isolated effect of cultivar (B), stem fresh biomass (C), shoot fresh biomass (D), root fresh biomass (E) total dry biomass $(\mathrm{F})$ as a function of the interaction between biochar rates and papaya cultivars $(\mathrm{V} 1=$ Formosa and V2 = Ouro). Means followed by the same letters do not differ within the same rate.

Similar to stem fresh biomass (Figure 3C), for shoot fresh biomass, cultivar Ouro (V2) showed better development with the increasing biochar rates, with a maximum value of $44.32 \mathrm{~g}$ at the estimated rate of
$13.53 \mathrm{t} \mathrm{ha}^{-1}$. Cultivar Formosa (V1) exhibited a quadratic behavior with a maximum estimated value of $36.86 \mathrm{~g}$ in plants subjected to the biochar rate of $10.425 \mathrm{t} \mathrm{ha}^{-1}$ (Figure 3D). 
The root fresh biomass data of the papaya seedlings (Figure $3 \mathrm{E}$ ) fit the quadratic model, with a decrease as the biochar rates were increased. Maximum estimated values for cultivars Formosa and Ouro were 33.74 and $29.11 \mathrm{~g}$, found at rates of 12.65 and $12.04 \mathrm{tha}$ 1 , respectively. These rates may have allowed greater physical conditioning of the substrate, with adequate porosity for each cultivar, resulting in better aeration for the root system. Combined with other characteristics of biochar, this enabled better root growth, which is essential for the survival of the seedlings.
Results for total fresh biomass were highest in seedlings produced at the rates of 11.3 and 12.9 t ha $^{-1}$, reaching maximum values of 70.2 and $73.26 \mathrm{~g}$ for $\mathrm{V} 1$ and $\mathrm{V} 2$, respectively (Figure 3F).

The interaction between biochar rates and papaya cultivars was significant for stem dry biomass, shoot dry biomass, root dry biomass, total dry biomass and Dickson Quality Index. The rate and cultivar factors were significant in isolation at $1 \%$ probability for leaf dry biomass (Table 4).

Table 4

Analysis of variance of the traits of leaf fresh biomass (LFB), stem fresh biomass (STFB), shoot fresh biomass (SHFB), root fresh biomass (RFB), total fresh biomass (TFB) and Dickson Quality Index (DQI) of papaya cultivars under biochar rates

\begin{tabular}{|c|c|c|c|c|c|c|}
\hline \multirow{2}{*}{ Source of variation } & \multicolumn{6}{|c|}{ Mean square } \\
\hline & LFB & STFB & SHFB & RFB & TFB & DQI \\
\hline Rate (D) & $1.3^{* *}$ & $12.29 * *$ & $20.05^{\star *}$ & 23.06 ** & $84.71^{\text {** }}$ & $4.79 * *$ \\
\hline Cultivar (V) & $3.36^{* *}$ & $0.53 n s$ & $1.22 \mathrm{~ns}$ & $0.02 \mathrm{~ns}$ & $0.92 n s$ & $0.004 n s$ \\
\hline $\mathrm{R} \times \mathrm{V}$ & $0.44 n s$ & $9.75^{* *}$ & $13.53^{* *}$ & $4.34^{*}$ & $22.15^{\star *}$ & $0.95^{* *}$ \\
\hline \multicolumn{7}{|l|}{ Rate within $\mathrm{V} 1$} \\
\hline Linear & - & $1.88^{*}$ & $1.07 n s$ & $8.41^{*}$ & $3.48 \mathrm{~ns}$ & $0.73 n s$ \\
\hline Quadratic & - & $25.52^{* *}$ & $40.79 * *$ & $26.77^{* *}$ & $133.66^{* *}$ & $5.63^{\star \star}$ \\
\hline Deviation & - & 17.37 & 22.79 & 8.36 & 57.5 & 2.41 \\
\hline \multicolumn{7}{|l|}{ Rate within V2 } \\
\hline Linear & - & $14.3^{* *}$ & $35.37^{* *}$ & $14.09^{* *}$ & $94.09 * *$ & $4.83^{* *}$ \\
\hline Quadratic & - & $14.12^{* *}$ & $20.13^{* *}$ & $23.5^{\star *}$ & $86.57^{* *}$ & $4.84^{* *}$ \\
\hline Deviation & - & 0.78 & 0.72 & 13.14 & 14.68 & 1.81 \\
\hline Residual & 0.25 & 0.027 & 0.82 & 1.33 & 3.06 & 0.22 \\
\hline CV (\%) & 28.92 & 22.05 & 19.72 & 26.35 & 19.51 & 22.94 \\
\hline \multicolumn{7}{|c|}{-----------------------------------g---------------------------------- } \\
\hline Mean & 1.72 & 0.75 & 4.59 & 4.38 & 8.97 & 2.04 \\
\hline
\end{tabular}

*, **significant at 0.05 and 0.01 probability, respectively, and ns not significant, by the $\mathrm{F}$ test; $\mathrm{CV}$ : coefficient of variation.

The regression equation of papaya seedlings as a function of the increasing biochar rates shows that leaf dry biomass
(Figure 4A) followed the trend of the other variables and fitted the quadratic polynomial model, with a maximum value of $2.05 \mathrm{~g}$ at the 
rate of $14 \mathrm{tha}^{-1}$. When we compare the cultivars, Ouro (V2) showed a better result for leaf dry biomass, with $1.93 \mathrm{~g}$, representing a difference of $35.62 \%$ in comparison with cultivar $\mathrm{V} 1(1.46$
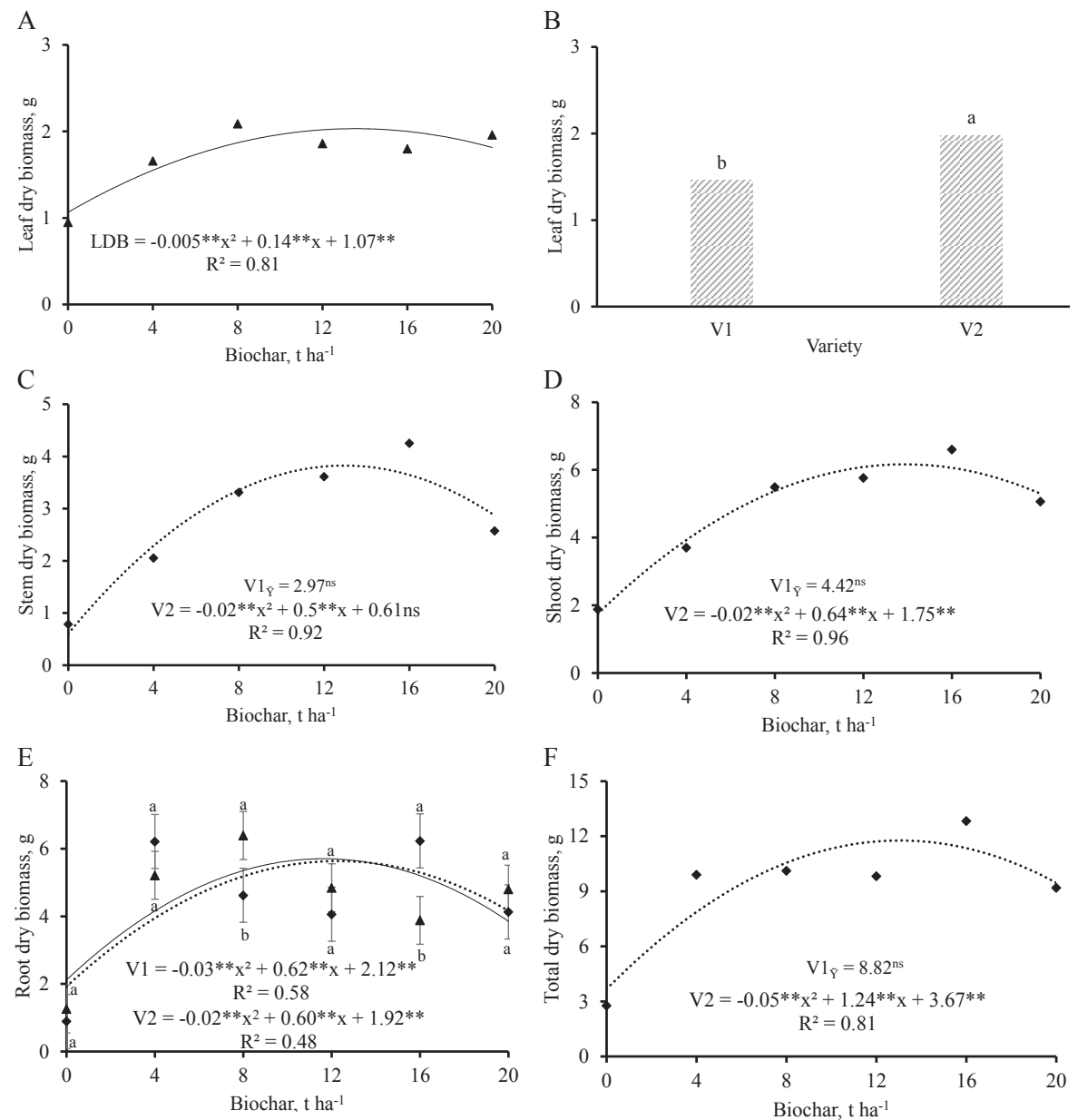

G

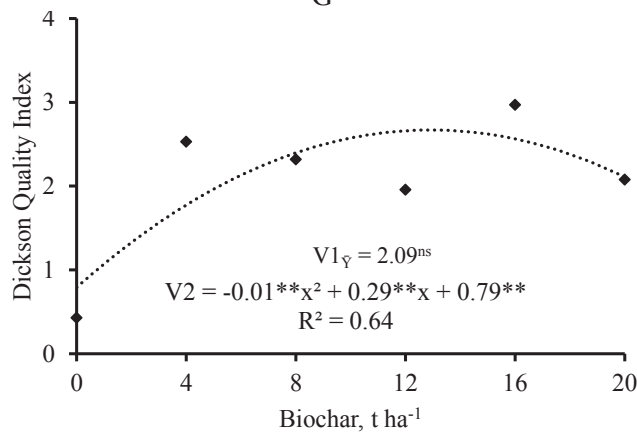

Figure 4. Leaf dry biomass as a function of the isolated effect of biochar rate $(A)$ and the isolated effect of cultivar (B), stem dry biomass (C), shoot dry biomass (D), root dry biomass (E), total dry biomass (F) and Dickson Quality Index (G) as a function of the interaction between biochar rates and papaya cultivars (V1 = Formosa and V2 = Ouro). Means followed by the same letters do not differ within the same rate. 
For stem dry biomass (Figure 4C), higher values were observed when the plants were fertilized with $12.5 \mathrm{t} \mathrm{ha}^{-1}$, which resulted in $3.735 \mathrm{~g}$. Shoot dry biomass (Figure 4D) also fitted the quadratic model, with a maximum estimated value of $6.87 \mathrm{~g}$ in the plants that received the biochar rate of $16 \mathrm{t} \mathrm{ha}^{-1}$. The increase in shoot dry mass resulting from biochar application corroborates R. V. D. Silva et al. (2019), who observed a $230 \%$ increase in shoot dry biomass relative to the seedlings grown without biochar.

The interaction between rates and cultivars significantly affected the root dry biomass of the papaya plants (Figure 4E). The regression equations revealed that the data had a better fit to the quadratic model, with the maximum estimated root dry biomass value of $5.32 \mathrm{~g}$ at the rate of $10.33 \mathrm{t} \mathrm{ha}^{-1}$ for cultivar Formosa and $6.42 \mathrm{~g}$ at the rate of $15 \mathrm{t} \mathrm{ha}^{-1}$ for cultivar Ouro.

Nonetheless, most likely due to the increase in salinity, biochar rates above adequate for the biomasses (fresh and dry) of the papaya seedling roots hampered the osmotic potential of the substrate, which caused a decrease in root length, making nutrient absorption difficult and thus compromising seedling development. These findings corroborate those described by Coelho, Silva, Silva, Sousa, \& Nobre (2015).

The interaction between biochar rates and papaya cultivars also significantly affected the total seedling dry biomass (Figure $4 \mathrm{~F})$, which exhibited a quadratic behavior, with an estimated maximum value of $11.36 \mathrm{~g}$ at the rate of $12.4 \mathrm{t} \mathrm{ha}^{-1}$.

Overall, even at certain levels (8 to $\left.12 \mathrm{t} \mathrm{ha}^{-1}\right)$, the presence of biochar in the substrate improved its chemical, physical and microbiological traits. This positively influenced the growth and development of papaya seedlings and, consequently, the root, stem, leaf, shoot and total dry biomasses, i.e., biochar had a good performance in seedling formation for both papaya cultivars. This may be attributed to its chemical constituents, especially phosphorus, which helps in the formation of the root system the organ through which nutrient absorption occurs, stimulating its growth; and of the shoots, besides other nutrients. Therefore, seedlings grown on substrate with biochar showed greater vigor as compared with those cultivated on substrate without biochar.

The DQI of the papaya seedlings (Figure $4 G$ ) showed a quadratic polynomial response and was significantly influenced by the interaction between biochar rates and papaya cultivars. Accordingly, this variable displayed an initial increase, followed by a decrease from the rate of $16 \mathrm{t} \mathrm{ha}^{-1}$, with maximum point estimated at 2.89, achieved at the rate of 14.5 $\mathrm{t} \mathrm{ha}^{-1}$ of poultry litter biochar. Seedlings that were cultivated at the rates of 4 and $16 \mathrm{t} \mathrm{ha}^{-1}$ of biochar in the substrate showed superior quality standards to the others. The Dickson Quality Index is considered a good indicator of seedling quality, as it takes into account several important morphological parameters such as height, stem diameter and plant dry matter, assuming that seedling survival is favored in field conditions (Saraiva, Souza, \& Rodrigues, 2014).

As stated by Hunt (1990), the minimum recommended value for the DQI is 0.20 . In the present study, this index ranged from 0.43 to 2.97 , demonstrating that the produced seedlings have appropriate quality to be planted in a definitive location, including those that were produced without the incorporation 
of biochar (DQI = 0.79). According to Albano et al. (2017), only the seedlings with the highest DQI value have a better quality standard, with better allometric characteristics, greater field survival capacity and less need for replanting in recovery areas. Thus, although all papaya seedlings produced showed a DQI value above the minimum recommended by Hunt (1990), the seedlings that received the rates of 4 and $16 \mathrm{t} \mathrm{ha}^{-1}$ stood out with a better relationship between the parameters, which results in a good final quality for establishment in the field.

\section{Conclusion}

Under the presented experimental conditions, the addition of poultry litter biochar promoted the growth of papaya seedlings as evidenced by the studied parameters, and the rates of 8 and $12 \mathrm{t} \mathrm{ha}^{-1}$ provided the best results. As for the studied cultivars, Ouro stood out over Formosa. Considering the advantages of poultry litter biochar in the composition of substrate, its use constitutes a viable alternative for the growth of papaya seedlings.

\section{References}

Albano, F. G., Cavalcante, Í. H., Machado, J. S., Lacerda, C. F. D., Silva, E. R. D., \& Sousa, H. G. D. (2017). New substrate containing agroindustrial carnauba residue for production of papaya under foliar fertilization. Revista Brasileira de Engenharia Agrícola e Ambiental, 21(2), 128-133. doi: 10.1590/1807-1929/agriam bi.v21n2p128-133

Alves, A. A., \& Santos, E. L. (2002). Estimativa da área foliar do mamoeiro utilizando medidas da folha. Anais do Congresso
Brasileiro de Fruticultura, Os Novos Desafios da Fruticultura Brasileira, Belém, PA, Brasil, 17.

Ayers, R. S., \& Westcot, D. W. (1999). A qualidade da água de irrigação na agricultura (2a ed.). Campina Grande: UFPB.

Chaves, L. H. G., Fernandes, J. D., Mendes, J. S., Dantas, E. R. B., Guerra, H. O., Tito, G. A., Chaves, I. B. (2020). Characterization of poultry litter biochar for agriculture use. Sylwan, 164(6), 468-487.

Coelho, D. C., Silva, E. C. B., Silva, F. M., Sousa, E. M. L., \& Nobre, R. G. (2015). Crescimento de mudas de mamoeiro em condições controladas com água salina. Revista Verde, 10(1), 1-5. doi: 10.18378/rvads. v10i1.3218

Cui, H.-J., Wang, M. K., Fu, M.-L., \& Ci, E. (2011). Enhancing phosphorus availability in phosphorus-fertilized zones by reducing phosphate adsorbed on ferrihydrite using rice straw-derived biochar. Journal of Soils and Sediments, 11, 1135-1141. doi: 10.1007/s11368-011-0405-9

Dickson, A., Leaf, A. L., \& Hosner, J. F. (1960). Quality appraisal of white spruce and white pine seedling stock in nurseries. The Forestry Chronicle, 36(1), 10-13. doi: 10.5558/TFC36010-1

Diniz, G. L., Sales, G. N., Sousa, V. F. O., Andrade, F. H. A., Silva, S. S., \& Nobre, R. G. (2018). Production $f$ papaya seedlings under water salinity irrigation and phosphate fertilization. Revista de Ciências Agrárias, 41(1), 218-228. doi: 10.19084/RCA17067

Empresa Brasileira de Pesquisa Agropecuária (2019). Plano estratégico para a cultura do mamoeiro 2017-2021. Cruz das Almas: EMBRAPA Mandioca e Fruticultura. 
Empresa Paranaense de Assistência Técnica e Extensão Rural (2011). Cama de frango vira adubo. Itaú de Minas,MG: Revista Globo Rural. Recuperado de http:// revistagloborural.globo.com/Revista/ Common/0,"EMI246995-18289,00CAMA +DE+FRANGO+VIRA+ADUBO.html

Ferreira, D. F. (2011). Sisvar: a computer statistical analysis system. Ciência e Agrotecnologia, 35(6), 1039-1042. doi: 10.1590/S1413-70542011000600001

Hafle, O. M., Santos, V. A. D., Ramos, J. D., Cruz, M. D. C. M. D., \& Melo, P. C. D. (2009). Produção de mudas de mamoeiro utilizando Bokashi e Lithothamnium. Revista Brasileira de Fruticultura, 31(1), 245-251. doi: 10.1590/ S0100-29452009000100034

Hoffmann, I., Gerling, D., Kyiogwom, U. B., \& Mané-Bielfeldt, A. (2001). Farmers' management strategies to maintain soil fertility in a remote area in northwest Nigeria. Agriculture, Ecosystems \& Environment, 86(3), 263-275. doi: 10.1016 IS0167-8809 (00) 00288-7

Hunt, G. A. (1990). Effect of styroblock design and cooper treatment on morphology of conifer seedlings. Proceedings of Target Seedling Symposium, Meeting of the Western Forest Nursery Associations, Roseburg, Oregon, Estados Unidos da América.

Instituto Brasileiro de Geografia e Estatística (2018). Produção agrícola municipal. Recuperado de https://sidra.ibge.gov.br/ tabela/5457\#resultado

Lima, R. S. N., García-Tejero, I., Lopes, T. S., Costa, J. M., Vaz, M., Durán-Zuazo, V. H., \& Campostrini, E. (2016). Linking thermal imaging to physiological indicators in Carica papaya L. under different watering regimes. Agricultural Water Management, 164(1), 148-157. doi: 10.1016/j.agwat. 2015.07.017

Lucchini, P., Quilliam, R. S., Deluca, T. H., Vamerali, T., \& Jones, D. L. (2014). Does biochar application alter heavy metal dynamics in agricultural soil? Agriculture, Ecosystems \& Environment, 184, 149157. doi: 10.1016/j.agee.2013.11.018

Maas, E. V., \& Hoffman, G. J. (1977). Crop salt tolerance - current assessment. Journal of Irrigation and Drainage Division, 103, 115-134.

Medeiros, M. B. C. L., Jesus, H. I., Santos, N. F. A., Melo, M. R. S., Souza, V. Q., Borges, L. S.,... Freitas, L. de S. (2018). Índice de qualidade de Dickson e característica morfológica de mudas de pepino, produzidas em diferentes substratos alternativos. Revista Agroecossistemas, 10(1), 159-173. doi: 10.18542/ragros. v10i1.5124

Mesquita, E. F., Chaves, L. H. G., Freitas, B. V., Silva, G. A., Sousa, M. V., \& Andrade, R. (2012). Produção de mudas de mamoeiro em função de substratos contendo esterco bovino e volumes de recipientes. Revista Brasileira de Ciências Agrárias, 7(1), 58-65. doi: 10.5039/agraria. v7i1a1448

Ministério da Agricultura, Pecuária e Abastecimento (2014). Manual de métodos analíticos oficiais para fertilizantes minerais, orgânicos, organominerais e corretivos. Brasília, Secretaria de Defesa Agropecuária: MAPA. 
Morgado, M. A. D. O., Bruckner, C. H., Rosado, L. D. S., Assunção, W., \& Santos, C. E. M. D. (2013). Estimação da área foliar por método não destrutivo, utilizando medidas lineares das folhas de espécies de Passiflora. Revista Ceres, 60(5), 662-667. doi: 10.1590/S0034-737X20 13000500009

Oliveira, A. M. G., Souza, L. D. S., Raij, B. V., Magalhães, A. D. J., \& Bernardi, A. D. C. (2004). Nutrição, calagem e adubação do mamoeiro irrigado. Cruz das Almas: EMBRAPA Mandioca e Fruticultura.

Paixão, M. V. S., Grobério, R. B. C., Fernandes, A. R., Farias, H. P. Jr., Meireles, R. C., \& Sousa, G. B. (2020). Esterco bovino e fertilizante na emergência e desenvolvimento inicial de plântulas de mamoeiro. Brazilian Journal of Development, 6(8), 5904859057. doi: 10.34117/bjdv6n8-354

Santos, C. C., Motta, I. D. S., Carneiro, L. F., Santos, M. C. S., Padovan, M. P., \& Mariani, A. (2014). Produção agroecológica de mudas de maracujá em substratos a base de húmus de minhoca e casca de arroz carbonizada. Cadernos de Agroecologia, 9(4), 1-10. Recuperado de http://revistas. aba-agroecologia.org.br/index.php/cad/ article/view/16399/10355

Saraiva, G. F. R., Souza, G. N., \& Rodrigues, J. D. (2014). Aclimatação e fisiologia de mudas de guarandi cultivadas em telas de sombreamento foto-protetoras. Colloquium Agrariae, 10(2), 1-10. doi: 10.5747/ca.2014.v10.n2.a102

Silva, I. C. B. D., Fernandes, L. A., Colen, F., \& Sampaio, R. A. (2017). Growth and production of common bean fertilized with biochar. Ciencia Rural, 47(11), e20170220. doi: 10.1590/0103-8478cr20170220
Silva, J. V. G., Longue, L. L., Santos Jardim, A. dos, Pinheiro, A. P. B., Rosa, R., Pagoto, A. L. R., \& Fernandes, A. A. (2021). Eficiência nutricional na produção de mudas de maracujazeiro azedo em função das concentrações de fósforo em solução nutritiva. Research, Society and Development, 10(4), e11510413988-e11510413988. doi: 10. 33448/rsd-v10i4.13988

Silva, R. V. D., Rodrigues, L. A., Silva, M. G. D., Silva, B. G. D., \& Martins, M. A. (2019). Biochar and mucuna increase papaya plant growth and nutrition, as well as soil fertility. Pesquisa Agropecuária Tropical, 49, e 55210. doi: 10.1590/198340632019v4955210

Siqueira, R. H. S., Chagas, E. A., Martins, S. A., Oliveira, A. H. C., \& Silva, E. S. (2020). Seleção de substratos para a produção de mudas de maracujazeiro-amarelo em Roraima. Amazonian Journal of Agricultural and Environmental Sciences, 63, 1-9.

Taiz, L., \& Zeiger, E. (2013). Fisiologia vegetal (5a ed.). Porto Alegre: Artmed.

Teixeira, P. C., Donagema, G. K., Fortana, A., \& Teixeira, W. G. (2017). Manual de métodos de análise de solo (3a ed.). Brasília, DF: EMBRAPA Solos.

Tito, G. A., Chaves, L. H. G., Dantas, E. R. B., Laurentino, L. G. S., Souza, F. G., \& Guerra, H. O. C. (2020). Biochar on soil chemical properties and beak pepper (Capsicun chinense) production. Agricultural Sciences, 11(12), 1133-1142. doi: 10.42 36/as.2020.1112074

Tofanelli, M. B. D., Santos, R. T., Schafhauser, J. D., \& Kogeratski, J. F. (2018). Complexo 
de elementos minerais hidrossolúvel na adubação de mudas de mamoeiro 'formosa'. Scientia Agraria Paranaensis, 17(3), 378-384.

Young, B. J., Rizzo, P. F., Riera, N. I., Torre, V. D., López, V. A., Molina, C. D., \& Sánchez, A. (2016). Development of phytotoxicity indexes and their correlation with ecotoxicological, stability and physicochemical parameters during passive composting of poultry manure. Waste Management, 54, 101-109. doi: 10.1016/j.wasman.2016.05.001

Zhai, L., Caiji, Z., Liu, J., Wang, H., Ren, T., Gai, X, Liu, H. (2015). Short-term effects of maize residue biochar on phosphorus availability in two soils with different phosphorus sorption capacities. Biology and Fertility of Soils, 51(1), 113-122. doi: 10.1007/s00374-014-0954-3 